International Journal of Social Sciences and Humanities
Available online at www.sciencescholar.us
Vol. 4 No. 3, December 2020, pages: 1 -12
e-ISSN: 2550-7001, p-ISSN: 2550-701X
https://doi.org/10.29332/ijssh.v4n3.434

\title{
COVID-19 Pandemic Handling Community Social and Cultural Sector Stimulus Efforts
}

\author{
I Nengah Merta ${ }^{\mathrm{a}}$, I Wayan Suderana ${ }^{\mathrm{b}}$ \\ Manuscript submitted: 18 April 2020, Manuscript revised: 27 May 2020, Accepted for publication: 09 July 2020
}

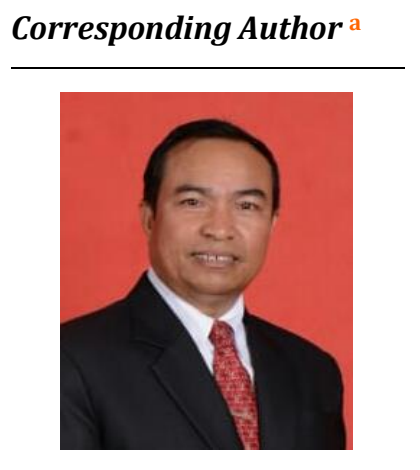

Keywords

COVID-19;

Handling pandemic; market residents; rural people; social and cultural stimulus;

\begin{abstract}
This study examines the COVID-19 Pandemic Handling Community Social and Cultural Sector Stimulus Efforts in Tambawu Village, Denpasar. The number of positive cases of outbreaks of coronavirus disease 2019 or COVID-19 due to the new type of coronavirus (SARS-CoV-2) in Bali, until June, reached 1,013 cases. Discipline and adherence to residents applying the COVID-19 prevention protocol, including implementing a clean and healthy lifestyle, is considered important in controlling the spread of COVID-19 infection. Of the total positive cases of COVID-19 in Bali which reached 1,013 cases, a total of 606 patients with positive cases of COVID-19 were reported to have recovered. The main problem in this regard: How is the effort to handle the COVID-19 pandemic so that it does not spread to the community? The Denpasar City Government has implemented a policy of limiting the activities of village-based, as an effort to control the spread of disease. The Government through the COVID-19 Task Force for the Acceleration of Handling of Health also conducts health checks through mass rapid tests in several places and communities that are indicated to be prone to disease transmission locally, including in markets and market residents.
\end{abstract}

International Journal of Social Sciences and Humanities (C) 2020.

This is an open access article under the CC BY-NC-ND license (https://creativecommons.org/licenses/by-nc-nd/4.0/).

\section{Contents}

Abstract

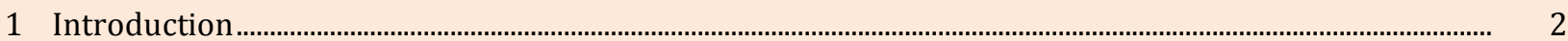

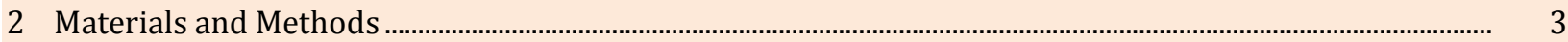

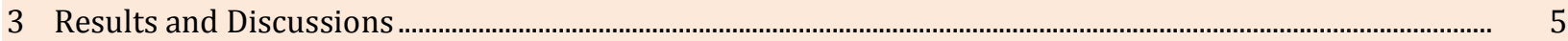

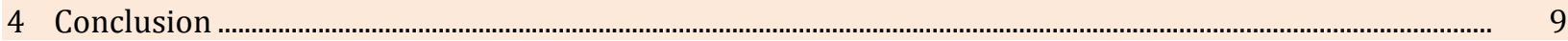

\footnotetext{
a STISPOL Wira Bhakti, Denpasar, Indonesia

${ }^{\text {b }}$ Universitas Pendidikan Nasional, Denpasar, Indonesia
} 


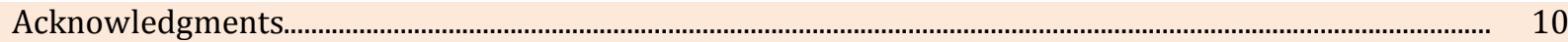

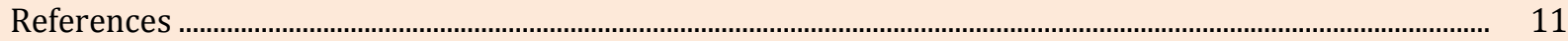

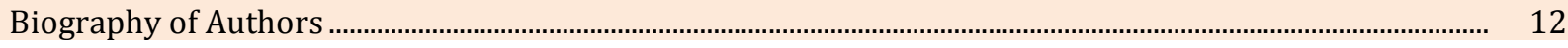

\section{Introduction}

Coronavirus is the most popular word in the world today. Because this virus is invisible has shocked the whole world after its appearance in Wuhan China late in 2019 then. From the third week to the end of the fourth week of March 2020, the spread of the coronavirus has become increasingly worrying. When China as the home country of the coronavirus announced a decrease in cases of corona infection, several countries in Asia, America, and Europe confirmed an extraordinary increase in sufferers. Even COVID-19 victims in the United States and Italy became the most in the world surpassing the case in China. Kompas.com (3/29/2020) launched 10 countries with the highest number of COVID-19 cases, namely: the United States $(123,271$ cases, 2202 deaths), Italy (92,471 cases, 10,023 deaths), China (81,394 cases, 3,295 deaths), Spain (73,235 cases, 5,982 cases), Germany (57,695 cases, 433 deaths), France (37,575 cases, 2,314 deaths), Iran (35,408 cases, 2,517 deaths), United Kingdom (17,089 cases, 1,019 deaths), Switzerland (14,076 cases, 264 died), the Netherlands $(9,762$ cases, 639 died). The official website of WHO records the widespread distribution of COVID-19 as of 30 March 2020 has reached 203 countries with 638,146 cases, and 30,105 patients died (www.who.int, 3/30/2020). In Indonesia, people with COVID-19 on March 29, 2020, reached 1,285 cases. 114 people died, while only 64 people recovered (cnnindonesia.com, 3/30/2020).

The Provincial Government of Bali, through the Task Force for the Acceleration of Handling Covid-19, announced the development of Corona Virus Disease Handling (COVID-19) in its region. The Chairperson of the Bali Province Co-19 Task Force for the Acceleration of Handling said that the number of co-19 positive patients was 66. COVID-19 in Bali June 2020, 11 People Healed. The number of people affected by COVID-19 increased by 66 people, totaling 895 people. 66 Indonesian citizens were added, with details of 2 PMIs and 64 local transmissions. From the description above, the main problem can be formulated in this case:

1) How is the government's handling of the Tambawu Village people affected by COVID-19?

2) How is the implementation to break the chain of transmission of the COVID-19 pandemic in the Tambawu Village, Denpasar, Bali?

\section{Literature review}

Some of the results of studies that have been conducted that are relevant and can be used as a reference in this study can be stated as follows. Based on tracing studies of the COVID-19 pandemic can be informed as follows. Research conducted by Susilo et al. (2020) with the title Against COVID-19. In early 2020, the world was shocked by the outbreak of new phenomena that began in Wuhan, Hubei Province which then spread rapidly to more than 190 countries and territories. This outbreak was named coronavirus disease 2019 (COVID-19) caused by Severe Acute Respiratory Syndrome Coronavirus-2 (SARS-CoV-2). The spread of this disease has had a wide social and economic impact. There are still many controversies surrounding this disease, including in aspects of establishing the diagnosis, management, and prevention. Therefore, we conduct a study of studies related to COVID-19 which have been widely published since the beginning of 2020 and then until the end of March 2020.

World Health Organization (WHO) on December 31, 2019, it is almost certain that no one thought the reality of the world would change into this. Even as the WHO recorded the first death due to this virus on January 11, 2020, the world did not budge. Some might think this will only happen in Wuhan, not in other parts of the world. Seeing the urgency of the situation and the increasingly widespread of the virus and the discovery of data that transmission has occurred locally in many countries, the Director-General of WHO announced the condition of world health emergencies (PHEIC) on 30 January. This gives a strong signal to the world that the outbreak that started in one city has spread to other places and has the potential to have an extraordinary impact on the world's population. If countries are not prepared to face it immediately, the risks faced will be very large, regarding all development sectors. Various scientific literature that reviews epidemics has underlined the importance of the readiness of each country is facing a new epidemic. Through the 
International Health Regulation (2005), WHO along with all its member countries, has also agreed to carry out this international treaty to increase the country's capacity to deal with outbreaks through preventative, detection and response approach. We know the Spanish flu epidemic in 1918, as well as polio, SARS, MERS$\mathrm{CoV}$, and ebola. But only the Spanish flu is classified as a pandemic because of its far-reaching impact on the lives of the world's population. Finally, after 102 years, on March 10, 2020, a pandemic was again announced for the disease under the name COVID-19.

In the face of SARS-CoV-2, the world seemed to be forced into a situation equivalent to World War III. In the $21^{\text {st }}$ century, the world war clashed with unseen enemies, but left more than 30,000 people dead and 500,000 more sick in 199 countries of the world. This enemy makes him feel alive in a similar reality, although not completely the same as a science fiction movie plot. It must be admitted that this situation puts mental stress on the high factor of ignorance and uncertainty about what can defeat it.

The latest research is Zahrotunnimah (2020) with the title Tactical Steps of Local Governments in Preventing the Corona COVID-19 Virus Spread in Indonesia. Since the World Health Organization or WHO has declared the Corona COVID-19 virus a pandemic. Following up on this, the Indonesian government also stated that the Coronavirus problem had become a non-natural national disaster. The President of the Republic of Indonesia and the Regional Government along with their staffs provided each other hand in hand to make some tactical steps as an effort to prevent the spread of Corona COVID-19 Virus in the community. From the ministerial level to the heads of the provinces, regencies, and even the municipal government. This research uses a content analysis method, where content analysis is limited to newspaper media which convey information related to some tactical steps taken by each head of government, both in several regions and countries. The purpose of this study is to provide education to the public in facing global disasters and their prevention. The results of the study showed that the local government had done a lot of communication strategies to the people of their respective regions through coercive, informative, canalizing, educative, persuasive and redundancy techniques in packaging messages in the form of instructions, appeals to the community to prevent COVID-19 transmission in their respective regions. However, there is still no coercive technique up to the stage of imposing sanctions for deterrent effects for offenders. The central government also has not yet maximized its role in using a comprehensive communication strategy for all local governments. This is because there is no national command from the central government which is known to be slow in preventing the transmission of COVID-19 which has become a global disaster.

\section{Materials and Methods}

\section{Data types and sources}

The data used in this study are:

1) Primary data, i.e. data and information obtained directly from sources/respondents. This data was obtained by conducting interviews with some Village officials and community recipients of COVID-19 assistance in Tambawu Village, Denpasar. By using a proportional sampling technique with a sample of 2 kelian banjar, 1 kelian adat, and 10 beneficiaries due to COVID-19.

2) Secondary data, namely supporting data and information obtained from the Tambawu Village Office in Denpasar.

\section{Research model specifications}

Peter Berger's Social Construction Theory in Demartoto (2013). Social construction (social construction) is a theory of contemporary sociology that is grounded in the sociology of knowledge. In this theory, there is an understanding that reality is socially constructed, and reality and knowledge are two key terms for understanding it. Reality is a quality found in phenomena that are recognized as having their being so they are not dependent on human will; whereas knowledge is the certainty that the phenomena are real and have specific characteristics. The world of daily life is something that comes from human thoughts and actions and is maintained as real in thoughts and actions. The basics of knowledge in everyday life are objectivation (objectification) of subjective processes (and meanings) through which the intersubjective world of common Merta, I. N., \& Suderana, I. W. (2020). COVID-19 pandemic handling community social and cultural sector stimulus 
sense is formed. In the objectification process, Berger and Luckmann emphasize the existence of awareness, and that awareness is always intentional because it is always directed at objects. The basis of consciousness (essence) can never be realized because humans only have awareness about something (phenomena); both concerning outward physical reality and inner subjective reality. Like humans, who also have an awareness of the world of daily life as perceived.

Herbert Spencer and Augus Comte's Theory of Evolution in Guma et al. (2014). The development of society in the 19th century according to Comte can reach a positive stage (positive stage). This stage is colored by how empirical knowledge is used to understand the social world as well as to create a better society. One or some changes always apply to all people at any time wherever they live and are. Ibn Khaldun, an Arab historian, analyzed the development of society, he said that the development of the community refers to its own rules, whereas social rules can only be known if the data collected were analyzed and sought correlation. Changes can occur quickly or slowly, changes that occur soon as we commonly call the revolution while changes that occur slowly or occur in a long time we usually call evolution. Therefore, the development of society is often analogous to the evolutionary process. a process of change that takes place very slowly. This thinking is very much influenced by the findings of biology, which have indeed developed rapidly. Layers of the rationale for social change as a form of "evolution" include Herbert Spencer and Augus Comte. Both have views about the changes that occur in a society in the form of linear development in a positive direction. Social change according to their view goes slowly but toward a form of "perfection" of society (Moleong, 2018; Klok et al., 2020; Tetro, 2020).

\section{Research location}

The location of this research is Tambawu Village, Denpasar. By observing and mapping measurable community activities. The observation time as the object of analysis was 12 (twelve) months from January to December running in 2019. The consideration of using 2019 was taken to facilitate the recording of information on respondents, namely, kelian banjar, kelian adat, and the beneficiary community of Covid19.

\section{Research instruments}

The instrument used in this research is descriptive research through literature surveys and field surveys and in-depth interviews. Interviews conducted are open-ended questions and closed-ended questions.

\section{Data analysis method}

The analytical method used in this study includes several methods following the objectives of the study are (1) The Theory of Berger and Luckmann's Social Construction in Demartoto (2013). A process of meaning carried out by each individual on the environment and aspects outside of himself consisting of the process of externalization, internalization, and objectivation. Externalization is an adjustment to the sociocultural world as a human product, objectivation is social interaction in an intersubjective world that is institutionalized or undergoes a process of institutionalization, and internalization is an individual identifying himself amid social institutions where the individual is a member. The term social construction of reality (social construction of reality) as a social process through actions and interactions where individuals create continuously a reality that is shared and experienced together subjectively (Poloma, 2004).

The origin of the social construction of the philosophy of constructivism that starts from cognitive constructive ideas. According to Von Glasersfeld, constructive cognitive notions appear in Mark Baldwin's writings which are widely deepened and spread by Jean Piaget. However, when traced, the main ideas of Constructivism have been started by Giambattista Vico, an epistemologist from Italy, he is the forerunner of Constructivism (Suparno, 2004). (2) Evolution Theory Herbert Spencer and Augus Comte in Guma et al. (2014). The development of society in the 19th century according to Comte can reach a positive stage (positive stage). This stage is colored by how empirical knowledge is used to understand the social world as well as to create a better society. One or some changes always apply to all people at any time wherever they live and are. Ibn Khaldun, an Arab historian, analyzed the development of society, he said that the development of the community refers to its own rules, whereas social rules can only be known if the data 
collected were analyzed and sought correlation. Changes can occur quickly or slowly, changes that occur soon as we commonly call the revolution while changes that occur slowly or occur in a long time we usually call evolution. Therefore, the development of society is often analogous to the evolutionary process. a process of change that takes place very slowly. This thinking is very much influenced by the findings of biology, which have indeed developed rapidly. Layers of the rationale for social change as a form of "evolution" include Herbert Spencer and Augus Comte. Both have views about the changes that occur in a society in the form of a linear development in a positive direction. Social change according to their view goes slowly but toward a form of "perfection" of society.

\section{Results and Discussions}

In the constructivist paradigm, social reality is a social construction created by individuals. Individuals are free human beings who have relations between one human with another. Individuals become determinants in the social world that are constructed based on their will. Individuals are not victims of social facts but as media of production as well as creative reproduction in constructing their social world (Sukidin, 2002).

Efforts made by Berger to restore the nature and role of the sociology of knowledge within the framework of the development of sociology. First, explain in detail the reality and knowledge in the social context of the Tambawu Village in Denpasar. The sociology theory must be able to explain that the life of the Tambawu Village in Denpasar is continuously being constructed. Everyday social symptoms of the community always proceed, which is found in the community experience. Therefore, the center of attention of the Tambawu Village in Denpasar is focused on the forms of comprehension (Erlebniss) of community life as a whole with all aspects (cognitive, psychomotor, emotional, and intuitive).

In other words, social reality is implied in social interaction, which is expressed as socially manifested in action. This kind of social reality in Tambawu Village is found in intersubjective experiences. Through intersubjectivity, it can be explained how the lives of certain people are formed in maintaining a healthy life and avoid COVID-19 continually. The concept of intersubjectivity refers to the dimension of the structure of general consciousness to individual consciousness in a particular group that is integrating and interacting with one another. Second, find the right methodology to examine the experience of intersubjectivity in the framework of constructing reality. In this case, indeed there needs to be an awareness that the so-called community of Tambawu Village in Denpasar must be built from an objective as well as a subjective dimension because the community itself is made culturally from the community (in which there is an intersubjectivity relationship) and humans are both the creators of their world. Therefore, in observing social phenomena that need to be selected, by paying attention to aspects of development, change, and social action. In this way, social order or social order can be understood by the people of Tambawu Village in Denpasar to break the COVID-19 chain and continue to pay attention to health protocols in everyday life. Third, choose the right and appropriate logic. Determined which logic needs to be applied to understand the social reality of the Tambawu Village community which has the characteristics that are plural, relative, and dynamic.

The Berger problem is logic that needs to be mastered so that the interpretation of sociology is relevant to the structure of general awareness. Berger holds that the sociology of knowledge should focus on the structure of the world of common sense (common sense world). In this case, social reality is approached from various approaches such as irrational mythological approaches, philosophical approaches that are moralistic, practical approaches that are functional, and all types of knowledge that build common sense. The complex, selective and accepting knowledge of the Tambawu Village in Denpasar causes the sociology of knowledge to select forms of knowledge that imply social reality and the sociology of knowledge must be able to see knowledge in the structure of individual consciousness and can distinguish between knowledge (subject and object affairs) and consciousness (subject matter with him).

Also, because the sociology of Berger's knowledge focuses on the world of common sense, it is necessary to use logical and non-logical principles. In a sense, contradictory and dialectical thinking (thesis, antithesis, synthesis). Sociology is required to have the ability to synthesize social phenomena that seem contradictory in a systematic, scientific, and convincing interpretation system. The ability of dialectical thinking is evident in Berger's thinking, as possessed by Karl Marx and some existential philosophers who recognize humans as

Merta, I. N., \& Suderana, I. W. (2020). COVID-19 pandemic handling community social and cultural sector stimulus efforts. International Journal of Social Sciences and Humanities, 4(3), 1-12. https://doi.org/10.29332/ijssh.v4n3.434 
paradoxical creatures. Therefore, it is not surprising that the reality of everyday life also has objective and subjective dimensions (Berger \& Luckmann, 1990).

Berger and Luckmann are of the view that reality is built socially, so the sociology of knowledge must analyze the process of that occurrence. In the sense of the individuals in the community of Tambawu Village in Denpasar, it is what builds the community, the individual experience is inseparable from the community. Waters said that "they started from the premise that human beings construct social reality in which the subject process can be objectified". (They start from the opinion that humans build social reality in which the process of relationships can be a coherent goal). It is this thought that perhaps underlies the birth of contemporary sociology theory (Sukidin, 2002). In the sociology of knowledge or the social construction of Berger and Luckmann, humans are seen as creating objective social realities through an externalization process, just as objective realities affect humans through the process of internalization (which reflects subjective reality). In the concept of dialectical thinking (thesis-antithesis-synthesis), Berger views the people of Tambawu Village Denpasar as human products and humans as community products. Berger's work explores various implications of objective and subjective reality dimensions and dialectical processes of objectivation, internalization, and externalization.

The theory of social construction Berger and Luckmann try to make a synthesis between social phenomena that are implied in three moments and bring up the construction of social reality which is viewed in terms of its origin is the result of human creation, artificial intersubjective interaction (Ali et al., 2020; Gilbert et al., 2020).

The Tambawu Village community in Denpasar is both an objective reality and a subjective reality. As an objective reality, the people of Tambawu Village in Denpasar seem to be outside themselves and face to face with them. Meanwhile, as a subjective reality, individuals are in that society as an inseparable part. In other words, individuals are forming society and society is forming individuals. The reality or social reality is double and not single, that is the subjective and objective reality. Reality or objective reality is a reality that is outside of human beings, while the subjective reality is the reality that is within human beings.

In this life, some rules or laws guide the various social institutions. The rule is a human product to preserve social order so that even though the rules in the social structure are restrictive, it does not rule out the possibility of "violations" committed by individuals. Violations of the rules that are caused by the changing externalization of the individual or in other words there is an inability of individuals to adjust to the rules used to maintain social order. Therefore, the problem of change is in this externalization process. So in a society that prioritizes "social order" individuals try as hard as possible to adapt to social roles that have been institutionalized, while for people who are happy with "social chaos" there will be more dislike to adjust to social roles that have been institutionalized.

This includes the people of Tambawu Village in Denpasar as an objective reality of legitimacy. The function of legitimacy is to make institutionalized objectivity make sense objectively. For example etiology, besides having the function of legitimacy to behavior and actions, also makes sense when the mythology is understood and carried out. To maintain the universe social organizations are needed. This is none other than because as a historical product of the human activity, all universally built societies will experience changes because of human activity so that social organizations are needed to maintain it (Kim \& Su, 2020; Tian et al., 2020; Sohrabi et al., 2020). When maintenance is built-in full force, then what happens is the status quo.

Tambawu Village Denpasar community is also a subjective reality or an internal reality. To become a subjective reality, we need socialization that serves to maintain and transform the subjective reality. Socialization always takes place within certain social structure concepts, not only in content but also in the degree of success. So the analysis of the micro-social or psychological social of the internalization phenomena must always be based on a socio-macro understanding of its structural aspects. To grow and foster a high sense of solidarity, social capital is needed.

Social capital comes from the interaction of various factors, each of which requires social relations that shape how agents react, and this reaction is formed by the existence of social capital. Social capital is a network, norms, and beliefs that facilitate cooperation and coordination. Therefore, social capital is believed to be the "spearhead" in overcoming existing diseases in society. The Central Statistics Agency (BPS) in 2014 in the social capital statistics explains how social capital is measured. Measurement instruments referring to World Bank instruments (Grootaert et al., 2004) are still relevant for driving social energy to overcome 
corona disasters. Following is the implementation of social capital in the context of overcoming the corona disaster.

From the description above it can be said that the attitude of mutual trust is needed to overcome the COVID-19 pandemic disaster. Mutual trust is needed both between communities and with policymakers. The public must believe in the government's COVID-19 disaster management policy scheme, while still thinking critically. Believe when asked to stay at home, work at home, eliminate crowded activities, not crowding, and so on to prevent the massive spread of the virus. Without public trust, the government's efforts to overcome the corona disaster will be in vain. Vice versa, the government must believe that people also do not stay silent. The community is helping, either by simply following the government's advice, or helping to overcome the lack of equipment and needs that the government has not been able to meet. For example the need for medical personnel, masks, hand sanitizers, food ingredients, and others. Together with teams such as the government, health experts and other industry associations work together to achieve an effective recovery protocol by developing meaningful action plans that optimize recovery efforts in all sectors. The health protocol provides insights \& tools for the public and private sectors for interaction and implementation to ensure that people feel safe from the spread of COVID-19 (Xie \& Zhu, 2020; Li et al., 2020; Moazzami et al., 2020).

Industrial society is based on friendship, unselfishness, elaboration of specialization, respect for achievement, and voluntary cooperation among highly disciplined individuals (Durham \& Douglas, 2006; John, 2003; Durham \& Kellner, 2012). The people of Tembau Village in Denpasar are united by voluntary relationship contracts and, more importantly, the same moral quality. Spencer used the word "industry" in the sense of spontaneous free cooperation for peaceful purposes. According to Spencer, the two types of people in Tambawu Village Denpasar contradict each other, Spencer uses the word social organism in terms of positivistic and deterministic. Tambawu Village Denpasar community is an organism, all social phenomena are explained based on a determination by natural law. Spencer distinguished four stages in the process of combining material. (1) The stage of multiplication or addition (2) The stage of complexification (3) The stage of division or differentiation (4) The stage of integration. Spencer's thought was strongly influenced by the biologist who originated the idea of evolution as a process of natural selection, Charles Darwin, by showing that social change is also a process of selection. The Tambawu Village Denpasar community develops with the Darwinian paradigm: there is a selection process in the Tambawu Denpasar Village community of the individuals. Spencer was analogous to society as the development of living things. Humans and people of Tambawu Village in Denpasar, including culture, have developed gradually. At first, it comes from a simple form and then develops in a more complex form towards the perfect final stage. Like Spencer, Comte's thinking was strongly influenced by natural science thinking.

Comte's thought, known as the flow of positivism, views that the people of Tambawu Village in Denpasar had to undergo various stages of evolution which at each of these stages were associated with certain thought patterns. Comte further explained that each emergence of a new stage would begin with the conflict between traditional thought and progressive thinking. As Spencer uses the analogy of the development of living things, Comte states that with the division of labor, the people of Tambawu Village in Denpasar will become increasingly complex, de-affiliated, and specialized. According to Comte, human development and thought, began at the theological stage in which case studies in primitive societies whose lives are still objected to nature, do not yet have the desire or mentality to control (managers) of nature or can be said to have not been subjected. Feminism and animism are the initial beliefs that shape the mindset of humans and then move to polytheism, humans assume there are spirits in every object that regulates life and the gods that regulate human will in each of their daily activities.

A more concrete example is Dewi Sri is a fertility goddess who stays in each field. The positive stage is the last stage of human thought and its development, at this stage natural phenomena, are explained by reason based on their laws which can be reviewed, tested, and proven empirically. This illumination produces instrumental knowledge, for example, when looking at the graves of people who have died at night always emit smoke (fog), and this is due to the combination of the cold of the night with nitrogen from soil content and insects that carry out chemical activities to decipher sulfur in human bones, eventually producing heat then emitting smoke. Like the description above that the development that occurs in the Tembau Village community in Denpasar will certainly cause a change in the community itself or commonly referred to as an event of social change. So social change is very closely related to evolution in the Tambawu Village community in Denpasar, so from that was born theory of evolution in a social context.

Merta, I. N., \& Suderana, I. W. (2020). COVID-19 pandemic handling community social and cultural sector stimulus efforts. International Journal of Social Sciences and Humanities, 4(3), 1-12. https://doi.org/10.29332/ijssh.v4n3.434 
Theory of Evolution in social contexts illustrates the development of society, first, namely the theory of evolution considers that social change is a direct movement like a straight line. The society developed from primitive society to a developed society. Second, the theory of evolution confuses the subjective view of values and the ultimate goal of social change. The change to the form of modern society is something that cannot be avoided. Because of that modern society is a form of society that is aspired to. In Tambawu Village, Denpasar, mechanically, small farmers live in a self-sustaining community and are intertwined together by a shared heritage and the same work. In modern, 'organic' societies, workers earn a salary and must rely on others who specialize in certain products (foodstuffs, clothing) to meet their needs.

As a result of this increasingly complex division of labor, that individual consciousness develops differently from collective consciousness - often clashing with the collective consciousness. It is not uncommon for a society that in addition to trying to carry out a process of modernization in various fields of life, whether it is economic aspects, bureaucracy, defense and security, and the field of science and technology; however, it did not escape the attention of the Tambawu Village community in Denpasar to try to explore, explore, and explore and find elements or values of personality or identity as a dignified nation. several factors give strength to the movement of change, which includes (1) an attitude, both individual and group scale, which can appreciate the work of other parties, regardless of the large or small scale of work productivity itself, (2) being able to tolerate some deviations from the forms or elements of the routine, because in essence one of the drivers of change is the existence of individuals who deviate from routine things.

Indeed, one of the essential features of a creature called a human being is a creature called homo deviant, a creature that likes to deviate from the elements of the routine, (3) affirming a habit or mental attitude that can give rewards to others parties (individuals, groups) who excel in innovation, both in the social, economic and science and technology fields, (4) the presence or availability of education and training facilities and services that have progressive, democratic specifications and qualifications, and are open to all parties who need them. In the implications of the theory of evolution, especially in handling COVID-19, it requires a comprehensive cognitive approach so that humanity can avoid this deadly plague.

Management of disease outbreaks must be done with a socio-cultural approach. Various efforts to manage epidemics throughout Bali provide information that handling outbreaks cannot be carried out by only involving the medical aspects. This is because disease outbreaks and socio-cultural aspects are two inseparable things. On one hand, the disease is often caused by human culture (ways of life), or at least disease easily becomes an epidemic due to certain cultures in society. On the other hand, the disease has an extraordinary impact on aspects of human culture. Cholera, for example, is known to arise from poor sanitation culture. The spread of cholera is possible because of an unclean lifestyle. On the contrary, since the cholera outbreak, people have had a new way of life, such as using a latrine with a septic tank system. Likewise, the current co-19 outbreak. This disease is transmitted between humans through close contact, therefore various community traditions such as festivity and parties may not be carried out for a while. It is not impossible after this epidemic ends, humans have a new way of life.

Because outbreaks are related to socio-culture, the handling must also consider socio-cultural aspects. In the current COVID-19 countermeasure, the government has paid attention to the socio-cultural aspects. For example (1) the appeal to create a task force up to the level of the Neighborhood Association, (2) campaigning the handling of COVID-19 with cooperation, (3) the government, in this case, the Directorate General of Culture makes a socialization video on co-19 prevention by using traditional content such as songs regions, traditional plays and so on, (4) lockdown options are not even chosen by the central government as a form of attention to social aspects.

But what has been done has not yet utilized the maximum cultural potential. On one hand, the government is campaigning for cooperation in handling co-19, but on the other hand, the government is calling on people to keep their distance and interaction with others. This has the potential to confuse the community. Also, this appeal for self-isolation coupled with information about how to spread the virus by making contact with others has the potential to make people have anti-social properties, at least temporarily. By isolating themselves, even at home, fellow community members may not know the condition of their neighbors, whether they are healthy, or whether they eat or not. Especially if the situation gets worse, human nature to survive will encourage the strengthening of selfishness. British sociologist Herbert Spencer said that to survive in severe or cruel conditions, humans need a selfish attitude to enable them to survive. Selfishness allows "the survival of the fittest" (Koentjaraningrat, 1981). 
This attitude is feared by the current government. If this happens, this attitude will lead to looting, and social chaos because humans are concerned with their interests and no longer care about the difficulties or suffering of others. Although Spencer's view is also widely denied by other philosophers who argue that humans survive with the principle of altruism (prioritizing shared interests), but with the conditions of a very capitalistic society today, where the right of private ownership is very large, Spencer's opinion is more likely to occur. To anticipate this happening the government can make some policies by making culture the spearhead.

The policy of making campaign materials based on local culture, but not limited to traditional art content as it already exists today. The cultural material used should be a local memory of the plague, which may be stored in folklore, songs, and so on so that the community immediately understands the impact that will occur. The use of collective memory is important because humans are easily mobilized if they have a relatively similar collective memory. Also, humans act according to their knowledge base, and human knowledge is composed of several elements, namely: perception, apperception, observation, concept, and fantasy. Therefore, if the government can stimulate the birth of appropriate apperception and fantasy, then appeals about social or physical distancing will be more obeyed by the community, without the need to use pressure.

Involving adat leaders, or other local agencies in conducting campaigns for COVID-19. The involvement of these local actors will have a significant impact because the appeals come from within themselves so that they are more heard. Denpasar City Government can also create or activate health posts in the smallest environment. Health agencies can appoint community health ambassadors and provide brief education about preventing the spread of the coronavirus. (3) If necessary, the government can stimulate the birth of customary rules or village regulations aimed at the successful handling and prevention of COVID-19. In many communities, customary rules or village regulations are sometimes obeyed more than government appeals. This is because customary and village rules are felt to be "closer" than government regulations.

Based on the description above, it can be explained that the process of evolution in society is very closely connected with the occurrence of social changes in society. The Tambawu Village Denpasar community who besides trying to carry out a modernization process in various fields of life, both from the economic, bureaucratic, security, and science and technology aspects; however, it did not escape the attention of the Tambawu Village community in Denpasar to try to explore, explore, and explore and find elements or values of personality or identity as a dignified society and nation.

The COVID-19 Pandemic paralyzed the economic sector of the Tambawu Village in Denpasar, so a food safety system needs to be considered. At the very least, some schemes guarantee adequate food for the lower class during the pandemic will be fulfilled. People who still live in the tribal system have an economic guarantee scheme called redistribution, this scheme can be applied to deal with the current epidemic. The Denpasar City Government may order each Dusun to form a Food Barn Team that is tasked with collecting donations or food contributions that will be distributed back to the people of Tambawu Village when food shortages occur during an outbreak. If the scheme is well managed, food security during the pandemic will be maintained, and this will be directly proportional to the prevention of looting and social unrest.

\section{Findings}

COVID-19's handling of cognitive needs is comprehensive so that humanity can avoid this deadly plague. Management of disease outbreaks must be done with a socio-cultural approach. Various efforts to deal with outbreaks throughout Bali and Denpasar in particular provide information that handling outbreaks cannot be done by only involving the medical aspects. The involvement of local actors such as kelian adat and banjar in Tambawu Village, Denpasar will bring a significant impact due to appeals come from within one's community so that more is heard.

\section{Conclusion}

First, Despite criticism from various groups, the government of Denpasar City and Tambawu Village are still focused on implementing social distancing and Community Activity Limiting policies to break the chain of distribution of Covid19. very bad for Denpasar Bali's economy. The lockdown scheme for Denpasar Bali has a Merta, I. N., \& Suderana, I. W. (2020). COVID-19 pandemic handling community social and cultural sector stimulus efforts. International Journal of Social Sciences and Humanities, 4(3), 1-12. 
far worse impact because it is largely the residents of Tambawu Village working in the informal sector. Second, in various online social networking media such as Facebook, Instagram, and WhatsApp scattered small people's comments about the quarantine policy. Those who generally work with daily income worry that the policy will hamper their income sources. On one hand their family life needs continue to run while on the other hand they have no savings enough to meet the needs during lockdown because of a mediocre income. Economic incapacity might also be experienced by middle class Tambawu villagers because this class of people has a consumptive lifestyle and has a debt bill to raise social status. The people of Tambawu Village in Denpasar need to carry out a strategy to deal with the COVID-19 outbreak by making the socio-cultural aspect the spearhead.

Acknowledgments

We are grateful to two anonymous reviewers for their valuable comments on the earlier version of this paper. 


\section{References}

Ali, S. A., Baloch, M., Ahmed, N., Ali, A. A., \& Iqbal, A. (2020). The outbreak of Coronavirus Disease 2019 (COVID-19)-An emerging global health threat.Journal of infection and public health. https://doi.org/10.1016/j.jiph.2020.02.033

Berger, P. L., \& Luckmann, T. (1990). The social of reality: a treatise in the sociology of knowledge.

Demartoto, A. (2013). The existence and the effect of sex tourism habitus in Bandungan, Central Java, Indonesia. Asian Social Science, 9(15), 93.

Durham, M. G., \& Douglas, M. (2006). Kellner. Media and Cultural Studies.

Durham, M. G., \& Kellner, D. M. (Eds.). (2012). Media and cultural studies: Keyworks. John Wiley \& Sons.

Gilbert, M., Pullano, G., Pinotti, F., Valdano, E., Poletto, C., Boëlle, P. Y., ... \& Gutierrez, B. (2020). Preparedness and vulnerability of African countries against importations of COVID-19: a modelling study. The Lancet, 395(10227), 871-877. https://doi.org/10.1016/S0140-6736(20)30411-6

Grootaert, C., Narayan, D., Jones, V. N., \& Woolcock, M. (2004). Measuring social capital: An integrated questionnaire. The World Bank.

Guma, S. R., Lee, D. A., Yu, L., Gordon, N., Hughes, D., Stewart, J., ... \& Kleinerman, E. S. (2014). Natural killer cell therapy and aerosol interleukin-2 for the treatment of osteosarcoma lung metastasis. Pediatric blood \& cancer, 61(4), 618-626. https://doi.org/10.1002/pbc.24801

John, T. (2003). Globalization and Cultural Identity. The Global Transformations Reader. An Introduction to the Globalization Debate, Polity Press, Cambridge.

Kim, S. W., \& Su, K. P. (2020). Using psychoneuroimmunity against COVID-19. Brain, behavior, and immunity. https://doi.org/10.1016/j.bbi.2020.03.025

Klok, F. A., Kruip, M. J. H. A., Van der Meer, N. J. M., Arbous, M. S., Gommers, D. A. M. P. J., Kant, K. M., ... \& Endeman, H. (2020). Incidence of thrombotic complications in critically ill ICU patients with COVID19. Thrombosis research. https://doi.org/10.1016/j.thromres.2020.04.013

Koentjaraningrat, R. M. (1981). Kebudayaan, Mentalitas dan Pembangunan [Culture, Mentality and Development]. Jakarta: Gramedia.

Li, P., Fu, J. B., Li, K. F., Liu, J. N., Wang, H. L., Liu, L. J., ... \& Tong, Z. D. (2020). Transmission of COVID-19 in the terminal stages of the incubation period: A familial cluster. International Journal of Infectious Diseases, 96, 452-453. https://doi.org/10.1016/j.ijid.2020.03.027

Moazzami, B., Razavi-Khorasani, N., Moghadam, A. D., Farokhi, E., \& Rezaei, N. (2020). COVID-19 and telemedicine: Immediate action required for maintaining healthcare providers well-being. Journal of Clinical Virology, 104345. https://doi.org/10.1016/j.jcv.2020.104345

Moleong, J. (2018). Lexy.(1998). Metodologi Penelitian Kualitatif.

Poloma, M. M. (2004). Love that Does Justice: An Exercise in Reflexive Sociology. The Love that Does Justice: Spiritual Activism in Dialogue with Social Science, 211-216.

Sohrabi, C., Alsafi, Z., O'Neill, N., Khan, M., Kerwan, A., Al-Jabir, A., ... \& Agha, R. (2020). World Health Organization declares global emergency: A review of the 2019 novel coronavirus (COVID-19). International Journal of Surgery. https://doi.org/10.1016/j.ijsu.2020.02.034

Sukidin, B. (2002). Metode Penelitian Kualitatif Perspektif Mikro. Surabaya: Insan Cendekia.

Suparno, P. (2004). Teori Inteligensi ganda dan aplikasinya di sekolah. Yogyakarta: Kanisius.

Susilo, A., Rumende, C. M., Pitoyo, C. W., Santoso, W. D., Yulianti, M., Herikurniawan, H., ... \& Chen, L. K. (2020). Coronavirus Disease 2019: Tinjauan Literatur Terkini.Jurnal Penyakit Dalam Indonesia,7(1), 45-67. http://dx.doi.org/10.7454/jpdi.v7i1.415

Tetro, J. A. (2020). Is COVID-19 receiving ADE from other coronaviruses?. Microbes and infection, 22(2), 72-73. https://doi.org/10.1016/j.micinf.2020.02.006

Tian, S., Hu, N., Lou, J., Chen, K., Kang, X., Xiang, Z., ... \& Chen, G. (2020). Characteristics of COVID-19 infection in Beijing. Journal of Infection. https://doi.org/10.1016/j.jinf.2020.02.018

Xie, J., \& Zhu, Y. (2020). Association between ambient temperature and COVID-19 infection in 122 cities from China. Science of the Total Environment, 724, 138201. https://doi.org/10.1016/j.scitotenv.2020.138201

Zahrotunnimah, Z. (2020). Langkah Taktis Pemerintah Daerah Dalam Pencegahan Penyebaran Virus Corona Covid-19 di Indonesia. SALAM: Jurnal Sosial dan Budaya Syar-i, 7(3), 247-260.

Merta, I. N., \& Suderana, I. W. (2020). COVID-19 pandemic handling community social and cultural sector stimulus efforts. International Journal of Social Sciences and Humanities, 4(3), 1-12. https://doi.org/10.29332/ijssh.v4n3.434 


\section{Biography of Authors}

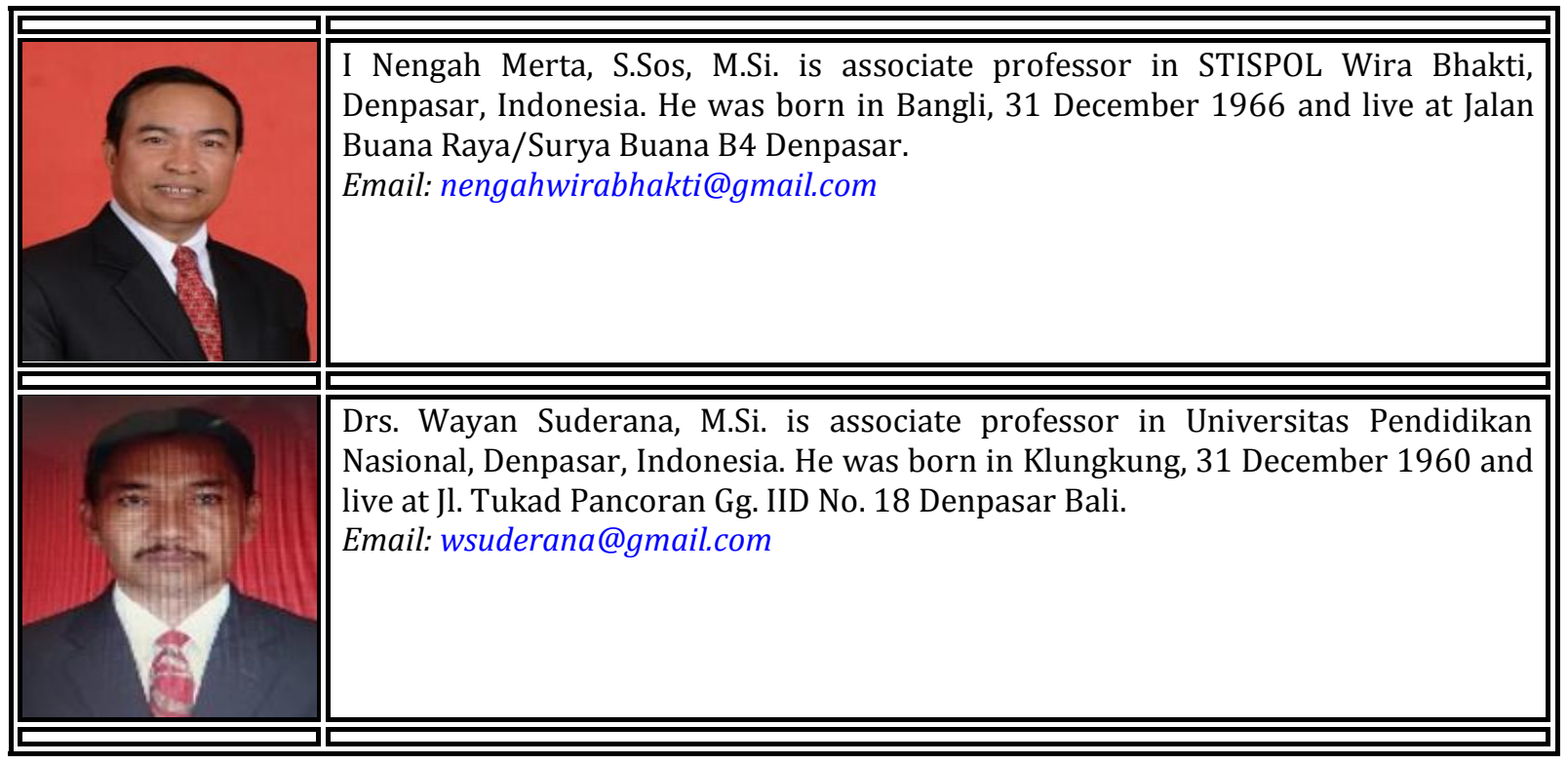

